\title{
QUALITATIVE AND QUANTITATIVE DETECTION OF LEAD BULLET FRAGMENTS IN RANDOM VENISON PACKAGES DONATED TO THE COMMUNITY ACTION FOOD CENTERS OF NORTH DAKOTA, 2007
}

\author{
William E. Cornatzer, Edward F. Fogarty, and Eric W. Cornatzer \\ University of North Dakota School of Medicine, Southwest Campus, \\ Bismarck, ND 58501, USA. E-mail: doccornatzer@qwestoffice.net
}

\begin{abstract}
We studied randomly selected ground venison packages donated to the Community Action Food Centers of North Dakota by the Hunters For The Hungry Association. These packages were studied by high resolution computerized tomography imaging and x-ray fluoroscopy for qualitative detection of metal fragments. Quantitative measurements of lead levels in both randomly selected and fluoroscopic image guided site-specific subsamples from packages were performed. This study documented a health risk from lead exposure to humans consuming venison. Received 30 July 2008, accepted 30 October 2008.
\end{abstract}

Cornatzer, W. E., E. F. Fogarty, AND E. W. Cornatzer. 2009. Qualitative and quantitative detection of lead bullet fragments in random venison packages donated to the Community Action Food Centers of North Dakota, 2007. In R. T. Watson, M. Fuller, M. Pokras, and W. G. Hunt (Eds.). Ingestion of Lead from Spent Ammunition: Implications for Wildlife and Humans. The Peregrine Fund, Boise, Idaho, USA. DOI 10.4080/ilsa.2009.0111

Key words: Computed tomography imaging, health risk, humans, lead, venison.

STUDIES OF LEAD TOXICITY in the diet of California Condors (Gymnogyps californianus) have shown there are small particles of lead in the tissues of deer shot with high velocity rifle bullets (Hunt et al. 2006). Reports from Canada and Greenland have shown a statistically significant correlation between elevated serum lead levels in people and the consumption of wild game killed with lead bullets (Bjerregaard et al. 2004, Dewailly et al. 2001, Tsuji et al. 2008). Preliminary research presented at The Peregrine Fund's Board of Directors meeting in May of 2007 (Parish pers. comm.) showed small metal fragments in processed venison. Based on these data, we conjecture that there might be lead fragments from rifle bullets in venison consumed by the general population.

\section{METHODS AND MATERIALS}

One hundred, one-pound ground venison packages were randomly selected from the Community Action Food Pantry program in North Dakota. The venison had been donated by the Hunters for the Hungry Program in the fall of 2007. The sample of 100 was selected from a total of 15,250 donated one-pound packages. High definition CT scan and fluoroscopy were performed on the sample for qualitative detection of metal fragments. In conjunction with the North Dakota Health Department, fifteen of the 100 randomly selected packages were punch biopsied in a blind fashion yielding 4-g tissue biopsies; this gave 15 random sub-samples from within the randomly selected packages. These specimens were sent to the University of Iowa Hygienic Laboratory for flame absorption atomic spectrometry to detect and quantify the mass of lead in sub-samples. An additional five samples ob- 
tained from among the $100 \mathrm{CT}$ screened packages using fluoroscopic image-guided retrieval of metalcontaining venison were also submitted for analysis. These image-guided biopsies yielded a maximum of four grams of combined ground venison and metal (Figure 1).

Osirix ${ }^{\circledR}$ DICOM ${ }^{\circledR}$ workstation software running on Mac OS $X^{\circledR}$ was used for visual analysis of CT image data for Hounsfield unit assessments of suspected lead fragments. Objects having Hounsfield unit measurements over 1500 were considered suspicious for metal fragments. Color look-up tables from Osirix ${ }^{\circledR}$ were used for color encoding of CT data.

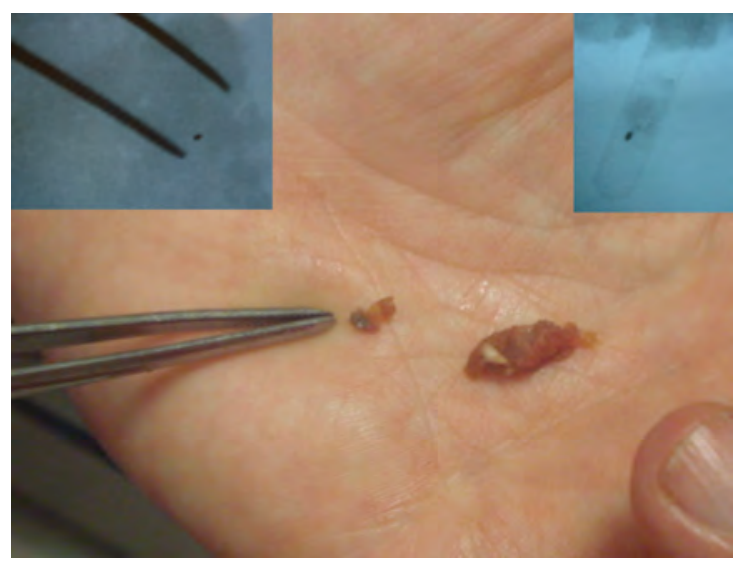

Figure 1. Fluoroscopic image-guided fragment sampling. The fluoroscopic image in upper left shows forceps approaching a metal fragment within a package of ground venison. The upper right image shows a retrieved metal fragment embedded within a small volume of ground venison contained in a glass test tube. Photograph shows forceps pointing to a metal fragment embedded in ground venison.

\section{RESULTS}

Qualitative analysis of the randomly selected ground venison samples showed 59 packages out of the 100 had one or more visible metal fragments on high definition computed tomography (Figure 2). Quantitative analysis with flame absorption atomic spectrometry of the fifteen random blind biopsies showed one sample with $120 \mathrm{ppm}$ lead $(1 \mathrm{ppm}=1$ milligram/kilogram). All five fluoroscopic imageguided biopsies showed elevated lead concentrations varying from 4,200 to 55,000 ppm lead dry weight (Table 1).

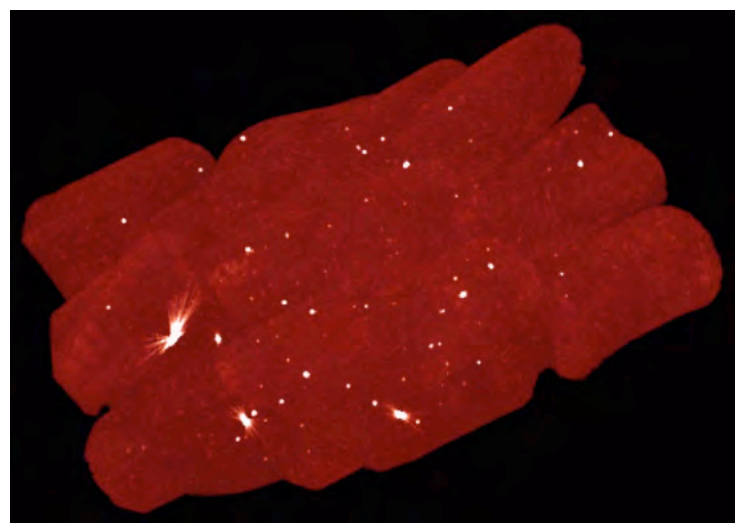

Figure 2. High definition computed tomography (CT) image of ca. 20 one-pound venison packages. Bright spots are metal fragments embedded in the tissue.

Table 1. Lead concentrations of five venison samples retrieved by fluoroscopically guided biopsy.

\begin{tabular}{cc}
\hline Sample & $\begin{array}{l}\text { Lead Concentration } \\
\text { (ppm or mg/kg dry weight) }\end{array}$ \\
\hline 1 & 52000 \\
2 & 34000 \\
3 & 4200 \\
4 & 55000 \\
5 & 9700 \\
\hline
\end{tabular}




\section{Discussion}

Our study has shown that $59 \%$ of 100 randomly selected packages of ground venison donated to the Community Action Food Pantry in North Dakota in the fall of 2007 were contaminated with lead fragments. Venison is a common dietary staple for many families throughout the United States. Lead has been shown to be a major health threat and in children there is no safe minimum threshold of lead exposure. Sources of dietary lead vary from country to country. In the United States, paint chips, dust, jewelry, toys, lead-based gasoline, and lead plumbing (Markowitz 2007) have been identified as sources of lead exposure in the past. Our study reveals lead-based ammunition residues in venison as a source of lead exposure among the USA population that is largely unrecognized as a threat to human health, other than among subsistence hunters of the circumpolar north including Alaska and Canada (Tsuji et al. 2008, Verbrugge et al. 2009, this volume).

\section{ACKNOWLEDGMENTS}

We thank the assistance of Terry Dwelle, M.D. and Sandy Washik of the North Dakota State Health Department, Steven Pickard, M.D., Field Officer of the CDC in the State of North Dakota, and Craig Lambrecht, M.D., Bismarck, North Dakota.

\section{Literature Cited}

Bjerregaard, P., P. Johansen, G. Mulvad, H. Pedersen, AND J. C. HANSEN. 2004. Environment lead sources in human diet in Greenland. Environmental Health Perspective 112 (15):1496-1498.

Dewailly, E. P., S. Ayott, S. Bruneau, G. LeBel, P. Levallos, AND J. P. WeBer. 2001. Exposure of the Inuit population of Nunivik (Arctic Quebec) to lead and mercury. Archives of Environmental Health 56:350-357.

Hunt, W. G., W. Burnham, C. N. Parish, K. Burnham, B. Mutch, AND J. L. OAKS. 2006. Bullet fragments in deer remains: implications for lead exposure in scavengers. Wildlife Society Bulletin 34:168-171.

MARKOWITZ, M. 2007. Lead Poisoning. Pages 2913-2918 in R. M. Kliegman, E. Behrman, H. B. Jenson, and B. F. Stanton (Eds.). Nelson Textbook of Pediatrics, $18^{\text {th }}$ ed. W. B. Saunders Co., Philadelphia, Pennsylvania, USA.

Tsuji, L. J. S., B. C. Wainman, I. D. Martin, C. Sutherland, J.-P. Weber, P. Dumas, AND E. NiEBOER. 2008. The identification of lead ammunition as a source of lead exposure in First Nations: The use of lead isotope ratios. Science of the Total Environment 393:291-298.

Verbrugge, L. A., S. G. Wenzel, J. E. Berner, AND A. C. MATZ. 2009. Human exposure to lead from ammunition in the circumpolar north. In R. T. Watson, M. Fuller, M. Pokras, and W. G. Hunt, (Eds.). Ingestion of lead from spent ammunition: Implications for wildlife and humans. The Peregrine Fund, Boise, Idaho, USA. DOI 10.4080/ilsa.2009.0110 